\title{
Biocomposites Based on Degradable Materials as Biotechnological Dermal Equivalents
}

\author{
Anna A. Shumilova*a, \\ Ivan P. Shidlovsky and Elena D. Nikolaeva ${ }^{\mathrm{b}}$ \\ ${ }^{a}$ Siberian Federal University \\ 79 Svobodny, Krasnoyarsk, 660041, Russia \\ ${ }^{b}$ Institute of Biophysics SB RAS \\ FRC "Krasnoyarsk Science Center SB RAS" \\ 50/50 Akademgorodok, Krasnoyarsk, 660036, Russia
}

Received 20.02.2018, received in revised form 02.04.2018, accepted 15.05.2018

Hybrid tissue-engineered biosystems based on biodegradable polymers of microbiological origin-bacterial cellulose (BC) and a copolymer of 3-hydroxybutyric and 4-hydroxybutyric acid $P(3 H B / 4 H B)$ - were constructed using various methods: 1) the dried BC pellicles were soaked with a $2 \%$ P $(3 H B / 4 H B)$ solution in chloroform, kept for $24 \mathrm{~h}$, and dried in a dust-free cabinet until the solvent had completely evaporated; 2) nonwoven membranes were placed into the K. xylinus B-12068 culture, and bacterial cellulose synthesized in it grew under static conditions; 3) powdered cellulose (particle size of $120 \mu \mathrm{m}$ ) was added to a $3 \% \mathrm{P}(3 \mathrm{HB} / 4 \mathrm{HB})$ solution in chloroform and mixed ultrasonically to homogeneity; then, the films were produced by the solvent evaporation technique, at polymer to cellulose ratios of 2:1 and 1:1. Investigation of surface properties of the samples showed an increase in surface hydrophilicity of the composites produced by mixing a solution of $P(3 H B / 4 H B)$ with $B C$ at ratios of $2: 1$ and $1: 1$ (the contact angle was $43.9 \pm 17.55^{\circ}$ and $36.1 \pm 0.66^{\circ}$ ) relative to the starting materials. The physical/mechanical properties of the composites based on $P(3 H B / 4 H B)$ and $B C$ were superior to the properties of the neat materials, and they were largely determined by the methods of production of the composite and the properties of the materials used. Based on the study of surface and physical/mechanical properties of the hybrids, films prepared by casting the polymer solution with BC powder (2:1 and 1:1) followed by solvent evaporation were chosen for studying cell adhesion. These scaffolds were loaded with drugs promoting wound healing (actovegin, solcoseryl) and tested in the culture of fibroblasts derived from the adipose tissue MSCs. The MTT assay showed that the most effective hybrid systems were polymer:bacterial cellulose powder (1:1) samples loaded with actovegin or solcoseryl at a concentration of 5\%. Those systems produced a stimulating effect on fibroblasts, and, thus, they can be regarded as promising wound dressings to repair skin defects.

(C) Siberian Federal University. All rights reserved

* Corresponding author E-mail address: shumilova.ann@mail.ru 
Keywords: bacterial cellulose, polyhydroxyalkanoates, hybrids, drugs, biocompatibility.

\title{
Биокомпозиты на основе разрушаемых биоматериалов в качестве биотехнологических дермальных эквивалентов
}

\author{
А.А. Шумилова ${ }^{a}$, И.П. Шидловскийа ${ }^{a}$ Е.Д. Николаева \\ ${ }^{a}$ Сибирский федеральный университет \\ Россия, 660041, Красноярск, пр. Свободный, 79 \\ ${ }^{6}$ Институт биофизики СО РАН \\ ФИЦ «Красноярский научный центтр СО РАН» \\ Россия, 660036, Красноярск, Академгородок, 50/50
}

\begin{abstract}
С применением различных методов конструирования матриксов получена и исследована серия гибридных тканеинженерных биосистем на основе биоразрушаемых полимеров микробиологического происхождения - бактериальной иеллюлозы (БЦ) и сополимера 3-гидроксимасляной и 4-гидроксимасляной кислот П(ЗГБ/4ГБ): 1) высушенные пленки БЦ погружали в 2\%-й раствор сополимера П(ЗГБ/4ГБ) в хлороформе на 24 ч и затем высушивали в беспылевом боксе до полного испарения растворителя; 2) нетканые мембраны П(ЗГБ/4ГБ), полученные методом электроспиннинга, помещзали в культуру K. xylinus B-12068, растущую и синтезируюшую БЦ в условиях периодической культуры; 3) к 3\%-му раствору П(ЗГБ/4ГБ) в хлороформе добавляли измельченную цчеллюлозу (размер частиц 120 мкм, в соотношении П(ЗГБ/4ГБ):БЦ 2:1 и 1:1), гомогенизировали ультразвуком, затем отливали пленки и сушили до полного испарения растворителя. Исследование свойств поверхности этих образијов показало повышение гидрофильности поверхности относительно исходных материалов для композитов, полученных путем смешивания раствора П(ЗГБ/4ГБ) с крошкой БЦ в соотношении

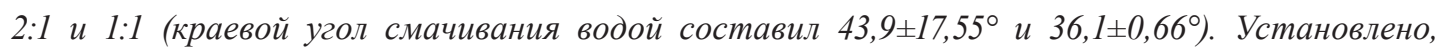
что физико-механические характеристики композитных матриксов во многом зависят от способа получения самого композита и свойств используемых материалов (П(ЗГБ/АГБ), БЦ) и превосходят последние. По результатам исследования поверхностных и физико-механических характеристик полученных гибридов для исследования адгезии клеток были отобраны пленочные системы, полученные технологией полива раствора полимера с иеллюлозной крошкой в соотношении 2:1 и 1:1 с последуюшим испарением растворителя. Эти типь матриксов были нагружены лекарственными препаратами, стимулирующими ранозаживление (актовегин, солкосерил) и протестировань в культуре фибробластов, полученных из ММСК жировой ткани. По результатам МТТ-теста наиболее привлекательными в качестве гибридных систем являются образиь «полимер:порошок бактериальной цуеллюлозы (1:1)», нагруженные актовегином или солкосерилом в концентраџчии $5 \%$, оказывающчие стимулирующее действие
\end{abstract}


на фибробласты, что дает возможность использовать их в качестве перспективньх раневых повязок для восстановления дефектов кожных покровов.

Ключевые слова: бактериальная иеллюлоза, полигидроксиалканоаты, гибриды, лекарственные препараты, биосовместимость.

\section{Introduction}

An essential requirement for effective treatment of skin injuries is the availability of biotechnological tissue-engineered skin equivalents. Materials used to fabricate such constructs should have a number of special properties and impart characteristics of living tissues to the engineered constructs (grafts). These characteristics include 1) the ability to regenerate themselves, 2) the ability to maintain the blood supply, and 3) the ability to alter their structure and properties in response to effects of the external factors, including mechanical loads (Zhang et al., 2016; Deng \& Kuipe, 2018; Han et al., 2014).

The main tasks of tissue engineering are to optimize isolation, proliferation, and differentiation of cells and to construct scaffolds or delivery systems for supporting and coordinating the growth of three-dimensional tissues in vitro. Scaffolds must serve as templates and inducers of cell proliferation and differentiation into specialized cells, generating new tissue. The tissue can be grown on the scaffolds that, being implanted into the host organism, will be gradually resorbed and replaced by the new tissue (Stratton et al., 2016; Shelke et al., 2014). Another option is to implant a biocomposite, which comprises a scaffold and a partly formed tissue. Having been implanted into the defect site, the engineered construct must retain its structure and functions over the time period necessary for the normally functioning tissue to be regenerated and integrated with the surrounding tissues (Shishatskaya \& Volova, 2016).
The purpose of the present study was to construct hybrid tissue-engineered biosystems for regeneration of injured skin based on materials of biotechnological origin (biocompatible and resorbable polyesters polyhydroxyalkanoates and bacterial cellulose).

\section{Materials and methods}

Bacterial cellulose (BC) pellicles were produced in the culture of acetic acid bacterium Komagataeibacter xylinus B-12068 (Prudnikova \& Shidlovsky, 2017); biodegradable polymer, poly-3hydroxybutyrate-co-4-hydroxybutyrate $(\mathrm{P}(3 \mathrm{HB} / 4 \mathrm{HB}))$, was synthesized in the culture of chemolithoautotrophic bacterium Cupriavidus eutrophus B10646 (Volova et al., 2014b).

Hybrids based on $\mathrm{BC}$ and $\mathrm{P}(3 \mathrm{HB} / 4 \mathrm{HB})$ were prepared using different methods: 1) the dried $\mathrm{BC}$ pellicles were soaked with a $2 \% \mathrm{P}(3 \mathrm{HB} / 4 \mathrm{HB})$ solution in chloroform, kept for $24 \mathrm{~h}$, and dried in a dust-free cabinet until the solvent had completely evaporated; 2) nonwoven membranes were placed into the K. xylinus B-12068 culture, and bacterial cellulose synthesized in it grew under static conditions; 3 ) powdered cellulose (particle size of $120 \mu \mathrm{m})$ was added to a $3 \% \mathrm{P}(3 \mathrm{HB} / 4 \mathrm{HB})$ solution in chloroform and mixed ultrasonically to homogeneity; then, the films were produced by the solvent evaporation technique, at polymer to cellulose ratios of 2:1 and 1:1. Solutions of actovegin (OOO Takeda Pharmaceuticals, RF) and solcoseryl (MEDA PHARMA, Switzerland) were used for the loading of $\mathrm{BC} / \mathrm{P}(3 \mathrm{HB} / 4 \mathrm{HB})$ hybrids by immersion in solutions of drugs. 
Samples of the $\mathrm{BC} / \mathrm{P}(3 \mathrm{HB} / 4 \mathrm{HB})$ hybrids were analyzed in a number of studies, to estimate their physical/mechanical and surface properties, their adhesive properties towards fibroblasts, and their ability to facilitate cell proliferation. The methods were described in detail elsewhere (Volova et al., 2014a).

Statistical analysis of the results was performed using the standard software package of Microsoft Excel. Arithmetic means for three replicates and standard deviations were found.

\section{Results and discussion}

The measurement of the mechanical properties produced the following results: composites of nonwoven membranes and $\mathrm{BC}$ had the highest values of Young's modulus (272.3 $\pm 27.2 \mathrm{MPa})$, most probably due to the high mechanical strength of the $\mathrm{P}(3 \mathrm{HB} / 4 \mathrm{HB})$ membranes $(113.54 \pm 9.85 \mathrm{MPa})$ (Table 1). The values of Young's modulus of the composite of the dried $\mathrm{BC}$ pellicles soaked in a $2 \% \mathrm{P}(3 \mathrm{HB} / 4 \mathrm{HB})$ solution was $110 \mathrm{MPa}$, while fracture strain increased to $6.25 \%$. Although Young's modulus of the composites prepared by mixing the polymer solution and $\mathrm{BC}$ powder was low $(65.08 \pm 7.1$ and $63.41 \pm 5.6 \mathrm{MPa})$, it was higher than the corresponding parameter of pure $\mathrm{BC}$ $(47.60 \pm 6.32 \mathrm{MPa})$.

Measurements of water contact angles showed that $\mathrm{BC}$ film was rather hydrophilic. Its water contact angle was $45.5 \pm 17.6^{\circ}$, while the water contact angle of the nonwoven $\mathrm{P}(3 \mathrm{HB} / 4 \mathrm{HB})$ membrane was $66.5 \pm 4.4^{\circ}$ (Table 1 ). Soaking of the $\mathrm{BC}$ film in a $2 \% \mathrm{P}(3 \mathrm{HB} / 4 \mathrm{HB})$ solution produced an insignificant effect on the surface properties of BC. Composites prepared by mixing the $\mathrm{P}(3 \mathrm{HB} / 4 \mathrm{HB})$ solution and $\mathrm{BC}$ powder at ratios of $2: 1$ and 1:1 had water contact angles of $43.9 \pm 17.55^{\circ}$ and $36.1 \pm 0.66^{\circ}$, respectively; the dispersive and polar components were larger than those of pure $\mathrm{BC}$, suggesting higher hydrophilicity of the surface of composites. The reason for the high values of water contact angle of the $\mathrm{BC}+$ nonwoven membrane composites, $65.3 \pm 2.72^{\circ}$, was that the nonwoven membranes used to grow cellulose were initially dense, with the water contact angle of about $60^{\circ}$.

An important parameter of wound dressings is water vapor transmission rate - a measure of the passage of water vapor through the material. The experimental composites showed different water vapor transmission rates: for the $\mathrm{P}(3 \mathrm{HB} / 4 \mathrm{HB})+\mathrm{BC}$ powder $(2: 1)$, it was the highest $\left(5014 \pm 20 \mathrm{~g} / \mathrm{m}^{2} \cdot \mathrm{d}\right)$, while for the $\mathrm{P}(3 \mathrm{HB} / 4 \mathrm{HB})$ film, it was the lowest $\left(404 \pm 9.1 \mathrm{~g} / \mathrm{m}^{2} \cdot \mathrm{d}\right)$. It is important to increase this parameter to control the build up of fluid underneath the dressing, make it more breathable, and prevent the establishment of conditions favorable for the development of pathogenic microorganisms.

The study of surface, physical/mechanical and biological properties of the experimental hybrids showed that the films prepared by casting the solutions of the polymer $\mathrm{P}(3 \mathrm{HB} / 4 \mathrm{HB})$ with cellulose powder followed by solvent evaporation were the most attractive candidates to be used as scaffolds for growing fibroblasts (Fig. 1). These types of hybrids were loaded with drugs promoting wound healing (actovegin, solcoseryl) and fibroblasts derived from the adipose tissue MSC (Fig. 1). Hybrids prepared by casting the solutions of the polymer: cellulose powder mixture (1:1) and loaded with $5.0 \%$ actovegin or solcoseryl were the most favorable for fibroblast growth.

\section{Conclusion}

Bacterial cellulose/resorbable polymer $\mathrm{P}(3 \mathrm{HB} / 4 \mathrm{HB})$ hybrid elastomeric systems were constructed as scaffolds for cell culture and as biotechnological dermal equivalents. The studies of the surface properties and physical/mechanical 


\begin{tabular}{|c|c|c|c|}
\hline 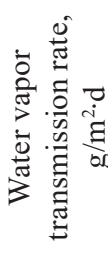 & 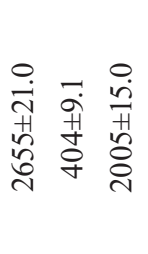 & 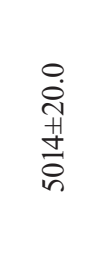 & 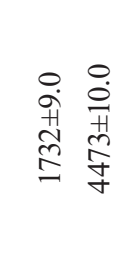 \\
\hline 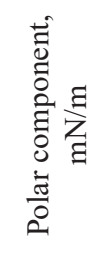 & 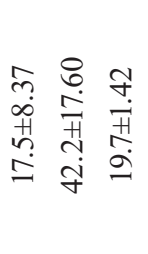 & $\begin{array}{l}\hat{D} \\
\infty \\
+1 \\
\dot{\vec{N}}\end{array}$ & 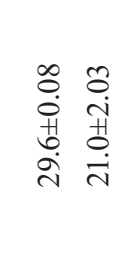 \\
\hline 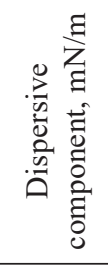 & 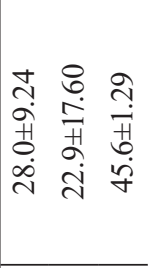 & $\begin{array}{l}2 \\
\text { aे } \\
\text { iे } \\
\text { ì } \\
\text { ते }\end{array}$ & 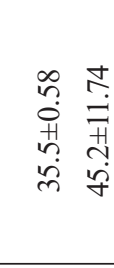 \\
\hline 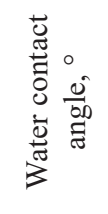 & 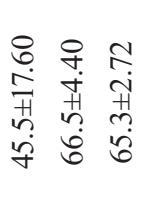 & 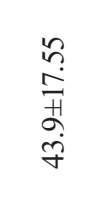 & 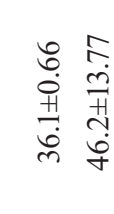 \\
\hline 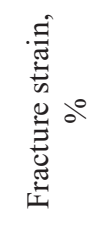 & 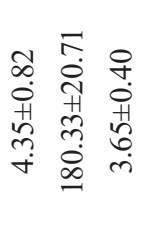 & 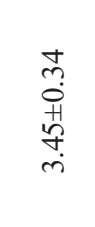 & 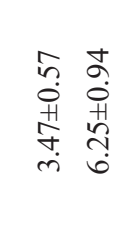 \\
\hline 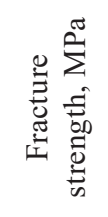 & 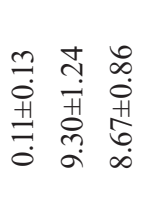 & $\begin{array}{l}\infty \\
0 \\
0 \\
+1 \\
\infty \\
\infty \\
0\end{array}$ & 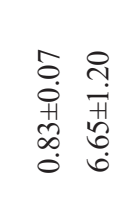 \\
\hline 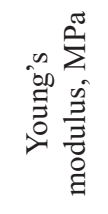 & 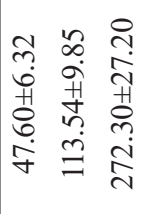 & $\begin{array}{l}0 \\
1 \\
1 \\
0 \\
0 \\
\dot{0}\end{array}$ & 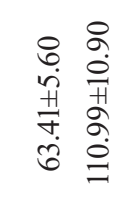 \\
\hline 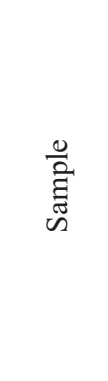 & 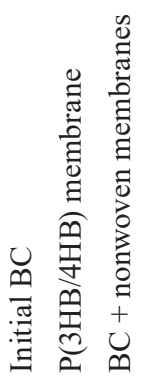 & 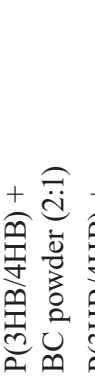 & 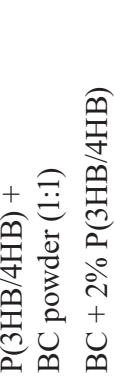 \\
\hline
\end{tabular}




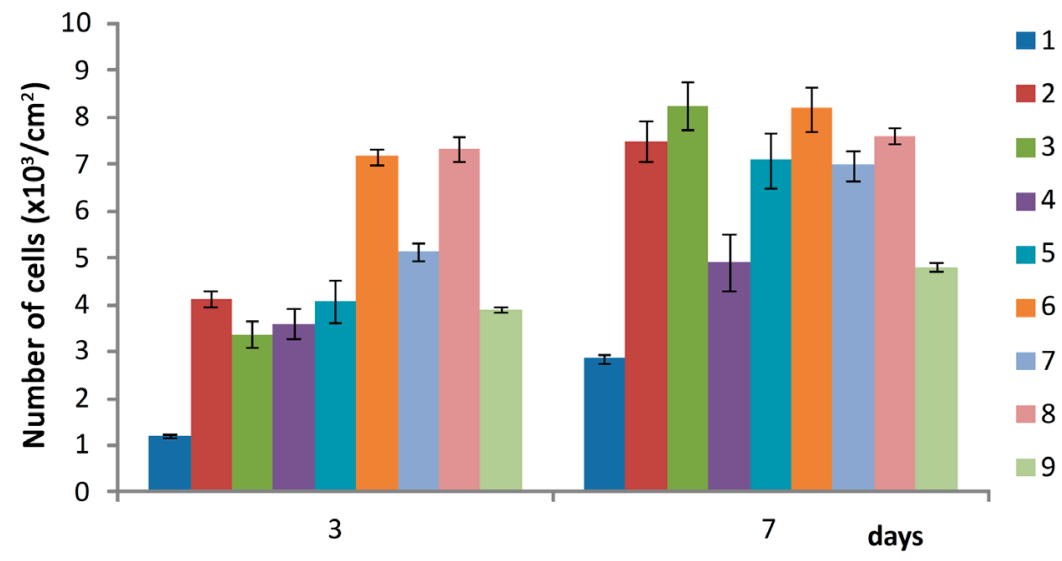

Fig. 1. Viable fibroblasts cultivated on $\mathrm{BC} / \mathrm{P}(3 \mathrm{HB} / 4 \mathrm{HB}) /$ drug hybrid scaffolds: 1 - control (polystyrene); $2-\mathrm{BC}+$ + nonwoven membrane; $3-\mathrm{BC}+2 \% \mathrm{P}(3 \mathrm{HB} / 4 \mathrm{HB})$ solution; $4-\mathrm{P}(3 \mathrm{HB} / 4 \mathrm{HB})+\mathrm{BC}$ powder $(2: 1) ; 5-\mathrm{P}(3 \mathrm{HB} / 4 \mathrm{HB})+$ $+\mathrm{BC}$ powder $(1: 1) ; 6-\mathrm{P}(3 \mathrm{HB} / 4 \mathrm{HB})+\mathrm{BC}$ powder $(1: 1)+\operatorname{actovegin}(5.0 \%) ; 7-\mathrm{P}(3 \mathrm{HB} / 4 \mathrm{HB})+\mathrm{BC}$ powder $(1: 1)+$ + actovegin $(1.0 \%) ; 8-\mathrm{P}(3 \mathrm{HB} / 4 \mathrm{HB})+\mathrm{BC}$ powder $(1: 1)+\operatorname{solcoseryl}(5.0 \%) ; 9-\mathrm{P}(3 \mathrm{HB} / 4 \mathrm{HB})+\mathrm{BC}$ powder $(1: 1)+$ + solcoseryl $(1.0 \%)$ (MTT assay)

properties of the hybrids proved that the best scaffolds, which facilitated fibroblast growth, could be produced by combining the cellulose/ polymer systems and drugs. They were found to be promising materials to fabricate wound dressings for healing skin defects.

\section{Acknowledgement}

The reported study was funded by Krasnoyarsk Regional Fund of Science according to the participation in the event/internship: "Analysis of GMOs using real-time PCR in food, food raw materials, feed and seeds".

\section{References}

Deng Y., Kuipe J. (2018) Functional 3D tissue engineering scaffolds: materials, technologies, and applications. Dakota, Woodhead Publishing, $482 \mathrm{p}$.

Han F., Dong Y., Su Z., Yin R., Song A., Li S. (2014) Preparation, characteristics and assessment of a novel gelatin-chitosan sponge scaffold as skin tissue engineering material. International Journal of Pharmaceutics, 476(1-2): 124-133

Prudnikova S.V., Shidlovsky I.P. (2017) The new strain of acetic acid bacteria Komagataeibacter xylinus B-12068 - producer of bacterial cellulose for biomedical applications. Journal of Siberian Federal University. Biology, 10(2): 246-254

Shelke N.B., James R., Laurencin C.T., Kumbar S.G. (2014) Polysaccharide biomaterials for drug delivery and regenerative engineering. Polymers for Advanced Technologies, 25: 448-460

Shishatskaya E.I., Volova T.G. (2016) Biomedical studies of polyhydroxyalkanoates. Journal of Siberian Federal University. Biology, 9(1): 6-20

Stratton S., Shelke N.B., Hoshino K., Rudraiah S., Kumbar S.G. (2016) Bioactive polymeric scaffolds for tissue engineering. Bioactive Materials, 1(2): 93-108

Volova T.G., Goncharov D.B., Sukovatyi A.G., Shabanov A.V., Nikolaeva E.D., Shishatskaya E.I. (2014a) Electrospinning of polyhydroxyalkanoate fibrous scaffolds: effects on electrospinning parameters on structure and properties. Journal of Biomaterials Science, Polymer Edition, 25(4): 370-393 
Volova T.G., Kiselev E.G., Vinogradova O.N., Nikolaeva E.D., Chistyakov A.A., Sukovatyi A.G., Shishatskaya E.I. (2014b) A glucose-utilizing strain, Cupriavidus euthrophus B-10646: growth kinetics, characterization and synthesis of multicomponent PHAs. PloS One, 9(2): e87551

Zhang X., Jia C., Qiao X., Liu T., Sun K. (2016) Porous poly(glycerol sebacate) (PGS) elastomer scaffolds for skin tissue engineering. Polymer Testing, 54: 118-125 